\title{
Rat bone marrow derived mesenchymal stem cells differentiate to germ cell like cells
}

Kuldeep Kumar ${ }^{1}$, Kinsuk Das ${ }^{1 \#}$, Madhusoodan AP ${ }^{1}$, Ajay Kumar ${ }^{2}$, Purnima Singh ${ }^{1}$ Tanmay Mondal ${ }^{1}$ and Sadhan Bag $^{1 *}$

${ }^{1}$ Division of Physiology and Climatology, ${ }^{2}$ Biochemistry and Food Science Section, ICARIndian Veterinary Research Institute, Izatnagar, Bareilly Uttar Pradesh, India.

\# Present affiliation: West Bengal University of Animal \& Fishery Sciences, Kolkata, India *Corresponding author: rplab1ivri@gmail.com

\section{$\underline{\text { Keywords }}$}

Mesenchyamal stem cells, Differentiation, germ cells.

\section{Summary Statement}

The in vitro differentiation of rMSCs provides an excellent model for studying cell commitment and their potential in stem cell technology. We have demonstrated that rat bone marrow derived MSCs are able to differentiate into germ-line cells in vitro which has an enormous scope in the advancement of fertility research. In future, this technique can be utilized in different domestic animal species for propagation of elite germ plasm.

\section{$\underline{\text { Abstract }}$}

Germ cells undergo distinctive male or female pathways to produce spermatozoa or oocyte respectively essential for sexual reproduction. Mesenchymal stem cells (MSCs) have the capacity of trans-differentiation to form the multiple lineages of cells of mesoderm, endoderm, and ectoderm origin. Herein, MSCs were isolated from rat bone marrow and characterized by their morphological features, expression of surface markers by immunophenotyping and 
molecular biology tools as well as self renewal and differentiation capability. Thereafter, by inducing these cells with retinoic acid we could able to show that bone marrow derived MSCs are able to trans-differentiate into male germ cell-like cells which were further characterized by the expressions of germ cell specific markers. This in vitro study for the generation of germ-like cells suggests that bone marrow MSCs can be a potential source of germ cells that could be a sustainable source of sperm / oocyte production for potential therapeutic applications in future. Moreover, this technique can be applied in different domestic animal species for propagation of elite germ plasm.

\section{$\underline{\text { Introduction }}$}

Bone marrow (BM) contains two types of cells; hematopoietic stem cells are responsible for the production of blood cells and, mesenchymal stem cells (MSCs) which have differentiation capability into the various cell lineages including adipocytes, chondrocytes and osteoblast (Friedenstein et al., 1974; Hunt et al., 2987; Prockop et al., 1997). Initially these cells were named as plastic-adherent or colony-forming unit fibroblast (CFU-F) which later on known as bone marrow stromal cells, mesenchymal stem cells (MSC) due to their heterogenous character and potentiality to differentiate into the various cells phenotypes (Jiang et al., 2002; Pittenger et al., 1999).

During last decade, MSCs have been isolated not only from bone marrow but also from different tissues of diverse species such as mice, rat, human, caprine, canine, equine, bovine, porcine, guinea pig etc. which could be differentiated into numerous cell types of mesodermal and non-mesodermal origin under appropriate conditions (Sung et al., 2008; Lotfy et al., 2014; Francis et al., 2009; Kumar et al., 2013; Das et al., 2017; Lange-Consiglio et al., 2013; Raoufi et al., 2011; Chen et al., 2016; Aliborzi et al., 2016). Few research works have demonstrated that MSCs not only inherently show a number of germ cell (GCs) characteristics but also in presence of certain chemical cue it may be propelled to GCs differentiation (Nayernia et al., 2006; Drusenheimer et al., 2007; Huang et al., 2010; Shirazi et al., 2012; Mazaheri et al., 2011). This differentiation potentiality into germ cells has paved the way for capitalizing these cells as a potential solution for infertility. Studies ranging from the chemical induction of MSCs to transplantation of MSCs into gonads have been performed to produce GCs (Nayernia et al., 
2006). In most of the ex vivo studies, retinoic acid (RA) have been used as potential cue for differentiation of MSC into germ cells because of its important regulatory role in embryonic patterning and development (Nayernia et al., 2006; Drusenheimer et al., 2007; Huang et al., 2010; Koubova et al., 2006).

MSC derivation from rat bone marrow has been reported earlier but, to the best of our knowledge its differentiation capability towards germ cell-like cells has not yet been recorded. Aim of the present study was to isolate MSCs from rat bone marrow, and to explore their differentiation potentiality towards germ cell-like cells. We successfully isolated and characterize MSCs and, were made to germ cell (GC) differentiation ex vivo with the induction of retinoic acid (RA) for 21 days. Confirmation of GCs was completed by morphological changes in MSCs over the time, germ cell specific gene expression by reverse transcription polymerase chain reaction (RT-PCR), immunophenotyping of cells with GC markers followed by flow cytometry based quantification of differentiated cells. The findings of this study may possibly be an insight cue for its prospective application in reproductive health.

\section{$\underline{\text { Results }}$}

\section{Isolation and characterization of bone marrow derived rMSCs:}

Rat bone marrow derived cells were noticed attached and proliferated onto the polysterin coated plastic surface of culture flask within 3 days after seeding. Initially different morphology of round and spindle shape of these cells was visualized which on subsequent passage falttened further to became fibroblastic in shape. Expanded cells after four passage appeared morphologically homogenous (Fig 1A).

Growth curve of rMSCs was obtained by counting the cells manually and the average of population doubling time was calculated based on the logarithmic growth phase. The average population doubling time was recorded $187.32 \mathrm{~h}$. CFU assay provided an evidence of these cells' proliferative and clonogenic capacity in culture system (Fig.1B).

In immunocytochemical staining cells were positive for MSCs specific surface markers, CD 73, CD 90, and CD 105 (Fig. 1C). Fluorescence activated cell sorting (FACS) revealed that the cells were positive for CD 73 (85.73\%), CD 90 (71.29\%) and CD 105 (79.55\%) (Fig. 1D). Further, gene expression followed by gel electrophoresis study revealed that distinct bands were 
expressed for MSC specific genes CD73, CD90, and CD105 whereas no band was noticed for CD45 (Fig. 1E).

Cells were able to differentiate to osteocytes, and chondrocytes under standard in vitro differentiating conditions. After osteogenic differentiation for 21 days prominent mineralized nodules were visualized in alizarin staining. Proteoglycan accumulation was noticed by Alcian Blue staining after 21 days of chondrogenic differentiation (Fig. 1F).

\section{In vitro differentiation of rMSCs into germ cell like cells}

After induction we noticed the effects of retinoic acid (RA) treatment on rMSC in terms of morphological changes at various time points. At the end of the treatment period changes in some of the cells' morphology towards germ-like cell in the culture was visualized (Fig. 2). Immunocytochemical staining for the germ cells markers like stella and fragilis were found positive in treated cells after 21days (Fig. 3A). These positive cells were quantified by FACS analysis, revealed that RA treatment led to the generation of $56.75 \%$ and $39.51 \%$ stella and fragilis positive cells, respectively (Fig. 3B). In RA treated cells, RT-PCR results detected the expression of stella and fragilis genes which are believed to be expressed at early stage of germ cell development. Moreover, we noticed the expression of other germ cell marker genes like cKit, Stra8, DAZL, Tex18, INGA6 and TP2 (Fig. 3C, D).

\section{$\underline{\text { Discussion }}$}

MSCs are a group of cells that can be found in various organs and tissues such as the bone marrow (BM), amniotic fluid, lungs, fat, peripheral blood, dental pulp, spleen, muscles, kidneys, and umbilical cord blood etc. Under appropriate conditions, they have the capacity to differentiate into numerous cell types and good option for use in cell therapy. Therefore, infertility researchers are motivated to use these cells as a potential solution for infertility. The approach of oocytes/ova production from MSCs may significantly improve fertility in female, elite animals and conservation of the germplasm of endangered and extinct species in future. The germ cell generation from MSC of various sources has enormous potential to increase animal reproduction. It offers the ability to produce animals of elite genetic potential from germ cells generated from MSC, if the ovum and semen are not available because of non-genetic reasons. 
Isolation and purification of rat MSCs is more challenging than other species due to its low abundance in bone marrow and also due to unwanted growth of non-mesenchymal cells during in vitro cell culture (Eslaminejad et al., 2006). In the present study, spindle-shaped fibroblast-like cells from rat bone marrow were purified by repeated medium change at initial phases of culture. Thereafter, in subsequent passage cells displayed the characteristic spindle shaped morphology of MSC which is commonly found in rat (Meirelles et al., 2003; Quiroz et al., 2008; Niyaz et al., 2012). The isolated cells displayed the formation of clones from single cells as determined by CFU assay. This assay demonstrate the capacity of cell to generate clones i.e. self-renewal ability, which is a typical characteristic of stem cell populations. Population doubling time was performed for measuring the time taken by the cells in doubling their number; result indicated that rat bone marrow MSCs are highly proliferative in nature. Lotfy et al., (2014) reported a higher proliferation rate of rat MSCs when derived from bone marrow as compared to its adipose tissue origin. Isolated cells expressed specific mesenchymal stem cell markers positive for CD73, CD90, and CD-105 whereas, negative for CD-45. Apart from this, the cells were able to differentiate into osteogenic and chondrogenic lineages. Similar reports have been published by other researchers while characterizing rMSC (Asumda et al., 2011; Sun et al., 2011; Zangi et al., 2006; Davies et al., 2015). Therefore, we presume that cell population isolated from rat bone marrow is of rMSCs and, these cells were used for our subsequent experiments.

The embryonic stem (ES) cells can be differentiated into germ cells in either by attachment culture or from embryoid bodies in vitro (Tilgner et al., 2008; Yamauchi et al., 2009; Lacham et al., 2006). Germ cells like cells have also been generated spontaneously from human ES cells which expressed different pre-meiotic and post-meiotic germ cells marker along with stem cells markers (Clark et al., 2006; Ginsburg et al., 1990). However, only few studies envisaged the potential of mice MSC towards germ cell lineage differentiation. These studies reported that mice MSCs under appropriate in vitro conditions can generate GCs (Nayernia et al., 2006; Drusenheimer et al., 2007; Huang et al., 2010; Shirazi et al., 2012). In the present study, we could able to generate germ cell-like cells after incubating the rMSC in RA following the method reported by Nayernia et al., (2006) in mice. RA is a crucial signaling molecule during vertebrate development, plays a key role in cell differentiation, proliferation and apoptosis (Miano et al., 2001). Moreover, it is considered as one of the important factors for inducing meiosis in differentiating mouse germ cells (Bowles et al., 2007). RA at high concentration $\left(10^{-5}\right.$ 
to $\left.10^{-6} \mathrm{M}\right)$ induces the formation of germ cells while its low concentration $\left(10^{-8}\right.$ to $\left.10^{-9} \mathrm{M}\right)$ promotes differentiation of MSCs towards smooth muscle and myocardial cells (Geijsen et al., 2004; Silva et al., 2009; Wobus et al., 2002). Herein, the differentiated cells resembled to the primordial germ cells of mice, human and primate (Shirazi et al., 2012).

Stella is a germ cell specific gene and amongst the first genes express in the differentiation process of GCs. It is believed that Stella is highly expressed in adult testicular spermatogonia (Lacham-Kaplan 2004). Moreover, it is involved in triggering GC competence and specification and in the delimitation of primordial GCs from their surrounding somatic cells (Aflatoonian and Moore 2005; Hayashi et al. 2007; Saitou et al. 2002; Saitou 2009). Expression of this marker in differentiated MSCs has been documented earlier (Nayernia et al. 2006; Qiu et al. 2013). Fragilis or interferon-induced transmembrane protein 3 (ifitm3) is also a GC-specific marker and an important factor for initiation of GCs specification and competence (LachamKaplan 2004; Lange et al. 2003). In our findings, we mostly focused on these two markers and, by immunophenotyping and gene expression studies and, could able to establish the differentiation of rat MSCs towards germ cell-like cells.

We also tested the differentiated cells for the expression of different germ cells specific markers viz. c-kit, stra8, DAZL, tex18, INGA6, TP2 by RT-PCR analysis and noticed the positive expression. Previous studies also reported that these markers are expressed during GC generation from MSCs under appropriate in vitro conditions (Saitou et al., 2002; Wang et al., 2001). DAZL contributes to the preliminary primodial germ cell formation by limiting both pluripotency and somatic differentiation (Niu et al.2014; Chen et al., 2014), and continues its expression in various types of goniocysts in prenatal and postnatal testes (Brekhman et al., 2000). In adult mouse and human testes DAZL is detected in spermatogonia, spermatocytes, and early round spermatids. Firstly it appears in mitotic spermatogonia, reaches peak in the cytoplasm of pachytene spermatocytes and ended in late sperm formation stage (Niu et al.2014). Previous studies also reported the ectopic expression of DAZL successfully promotes meiotic progression of PGC-like cells in human ESCs and iPSCs, as well as in DAZL-derived mESCs (Medrano et al., 2012; Ramos-Ibeas et al., 2015). Stra8 has emerged as a gatekeeper for the entry of germ cells into meiosis which is indispensable for premeiotic DNA replication and subsequent entry into the prophase of meiosis I (Mark et al., 2008; Baltus et al., 2006). Stra8 was previously 
used to construct the germ cell specific reporting vector Stra8-EGFP in the generation of male germ cells from mouse iPSCs and spermatogonial stem cells in vitro (Li et al., 2014). c-Kit has a similar effect and essential to the process of germ cell migration, proliferation, and survival in the gonadal anlage, and it is also involved in the reprogramming of PGCs (Hoyer et al, 2005). The molecular markers such as fragilis, stella, c-Kit, Tex18, Stra8, Dazl, TP2 and inga6 analyzed in these study have been identified earlier as the evidence of germ cell differentiation and for spermatogonia and SSCs (Saitou et al., 2002; Vincent et al., 1998; Wang et al., 2001; OuladAbdelghani et al., 1996; Cooke et al., 1996 and Shinohara et al., 1999).

\section{$\underline{\text { Materials and methods }}$}

\section{Experimental Animals:}

The adult Sprague dawley rats were collected from the laboratory animal house, Indian Veterinary Research Institute, Izatnagar, Bareilly and maintained under standard management practice. The animal care, handling as well as experimental protocols were approved by the Institutional Animal Ethics Committee (IAEC) of the Indian Veterinary Research Institute, which has the approval of the Committee for the Purpose of Control and Supervision of Experiments on Animals (CPCSEA) under the Ministry of Environment, Forests and Climate Change, Government of India.

\section{Isolation and culture of rat bone marrow derived MSCs:}

The isolation of rat MSC was following the protocol described by Nayernia et al., 2006. Briefly, adult rats were sacrificed under anesthesia and, femora and tibias of both the sites were aseptically removed. These bones after thoroughly washing with sterile PBS were flushed out with Dulbecco's Modified Eagle's Medium (DMEM) to get the bone marrow cells. The released cells were collected into $90 \mathrm{~mm}$ culture dish and finally plated at a density of $10^{5}$ cells $/ \mathrm{cm}^{2}$ in tissue culture flask (Nunc, Germany) with DMEM-low glucose medium supplemented with 10\% FBS, L-glutamine $(2 \mathrm{mM})$, penicillin $(100 \mathrm{U} / \mathrm{mL})$, streptomycin $(100 \mu \mathrm{g} / \mathrm{mL})$ and amphotericin B $(0.25 \mu \mathrm{g} / \mathrm{mL})$ (all from Thermofisher), and maintained at $37^{\circ} \mathrm{C}$ in a humidified atmosphere of $5 \%$ $\mathrm{CO}_{2}$. Cells upon reaching $70-80 \%$ confluence were serially passaged by detaching with $0.25 \%$ Trypsin-EDTA (Invitrogen). To define these cell population as multipotent MSCs we characterized them to meet the minimal criteria like morphology, plastic adherent property, colony forming ability, expression of MSC specific surface markers (+/CD 73, CD 90, CD 105 
and -/ for CD 45) and the ability for multiple-lineage differentiation in vitro. The population of rat MSCs (rMSCs) was expended upto 6 passages for our experiments.

\section{Growth kinetics and colony forming unit assays of rMSCs}

The growth kinetic study was performed by harvesting followed by counting the trypsinized cells manually. rMSCs were cultured in 12 well plate at a plating density of 50,000 cells/well. The number of cells of each plate was counted on every day. The population doubling time of cells was estimated on logarithmic growth phase based of the cell growth curve. To assess the capacity and efficiency for self renewal, cells (Passage 2) were seeded at low density in 6-well culture plate $\left(50\right.$ cells $\left./ \mathrm{cm}^{2}\right)$ and new fibroblast colonies derived from single cells were counted. After 15 days of culture the plates were fixed and stained with $1 \%$ crystal-violet in $100 \%$ methanol (Kumar et al., 2016)

\section{Immunofluorescence staining and flow cytometry of rMSCs}

The immunocytochemical staining of rMSCs was done with MSC specific positive markers like CD73, CD90 and CD105 and, with CD45 as a negative marker. The rMSCs were grown over cover slip and, were fixed with $4 \%$ paraformaldehyde, washed with PBS, permeabilized with $0.25 \%$ Triton X-100 in PBS followed by blocking nonspecific binding sites with $10 \%$ normal goat serum in PBS for $1 \mathrm{~h}$ at RT. The cells were then incubated with primary antibodies (1:100; Santa Cruz) of CD73, CD90, CD105 and CD45 for overnight at $4^{0} \mathrm{C}$. After thorough washing, the cells were further incubated with FITC conjugated secondary antibodies (1:500; Santa Cruz) for $4 \mathrm{~h}$ at darkness followed by counter staining with DAPI ProLong Gold antifade solution (Invitrogen). Cells were imaged under an inverted fluorescence microscope (Carl Zeiss) with Axio Vision 4.0 image analysis system. To evaluate the homogenecity of rat MSCs, cells were analyzed by flow cytometry. Aliquots containing 1 X $10^{6}$ cells for each marker were separately fixed, permeabilized, blocked followed by incubation with primary and secondary antibodies as per the standard immunocytochemical staining protocol with the same combinations of antibodies used for each marker. Flow cytometer (FACS Calibur, BD Bioscience, USA) settings were established using unstained cells. Data was analysed by recording 10,000 events with Cell Quest Pro software (BD Bioscience, USA). 


\section{In vitro differentiation of $\mathrm{rMSCs}$}

To induce osteogenic differentiation, rMSCs were plated in a six well plate tissue culture dish in MSC medium. After $48 \mathrm{~h}$ of culture, the media was replaced with osteogenic differentiation medium (DMEM containing 10\% FBS and 10 nmol- Dexamethasone, 10 mmol $\beta$-glycerophosphate, $0.3 \mathrm{mM}$-L-ascorbic acid) upto 21 days with adding fresh differentiation media at every 48-72 $\mathrm{h}$ interval. The osteogenic differentiation was visualized by Alizarin red cytochemical staining. For chondrogenic differentiation, the cells were cultured in chondrogenic induction medium consisting of DMEM containing 10\% FBS, 100 nmol-Dexamethasone, 1 mmol sodium pyruvate, L-ascorbic acid $(50 \mu \mathrm{g} / \mathrm{ml})$, TGF- $\beta 1$ (10ng/ml and ITS 1\%). The induction medium was changed after every $3^{\text {rd }}$ day. At the end of the induction, the cells were fixed with 4\% paraformaldehyde for $10 \mathrm{~min}$ and were stained for the alcian blue staining.

\section{Gene expression study}

Cells were harvested from monolayer culture and washed with PBS. The total RNA was isolated by Quick-RNATM MicroPrep (Zymo Research). Total RNA was quantified, and quality was ascertained (OD 260/280 > 1.6) using NanoDrop (Eppendrof, USA) as well as gel electrophoresis. A total of $1 \mu \mathrm{g}$ RNA was reverse-transcribed to synthesize complimentary DNA (cDNA) using iScript ${ }^{\mathrm{TM}}$ cDNA Synthesis kit (Bio-Rad, USA). The expression of MSC specific genes CD73, CD90, CD105 and CD45 was assessed by RT-PCR method with specific primers (Table 1) by using EvaGreen supermix (Bio-Rad). Each PCR product was size-fractionated by $2 \%$ agarose gel electrophoresis, and the bands were visualized with a UV trans-illuminator (BioRad).

\section{Induction for germ cell differentiation}

The differentiation of rat MSC into GCs was induced by the method described by Nayernia et al., (2006). Briefly, the semi confluent cells were treated in MSC culture medium with supplementation of $10^{-6} \mathrm{M}$ RA (Sigma) and maintained at $37^{\circ} \mathrm{C}$ in a humidified atmosphere of $5 \% \mathrm{CO}_{2}$ for 21 days. After induction we looked into the effects of retinoic acid (RA) treatment on rMSC in terms of morphological changes at various time periods of 3, 7, 14 and 21 days as well as expressions of GC-specific genes, immunocytochemical staining followed by flow cytometry at the end. 


\section{Molecular characterization}

Total RNA was extracted and cDNA was prepared from the differentiated cells after 21 days. RT-PCR gene expression analysis was carried out using the Real-Time PCR System (BioRad) with rat specific primers (Table 1) for the germ cell marker genes like Stella, Fragilis, cKit, Stra8, DAZL, Tex18, INGA6 and TP2. Size-fractionation of PCR products were done as per previously mentioned protocols.

\section{Immunocytochemistry}

In order to confirm the differentiation of rMSCs into GCs, we performed immunostaining for expression of GCs specific markers Stella and Fregilis. rMSCs were differentiated over coverslips which was kept inside each well of the 6 well plate. The cells were subsequently fixed and stained with antibodies according to a previously described method (Kumar et al., 2014)

\section{Flow cytometry assay of germ cells}

Following differentiation, the cells were harvested by trypsinization and collected by centrifugation followed by washing with PBS. Cells for each marker were separately fixed, permeabilized, blocked followed by incubation with primary and secondary antibodies (Stella \& Fragilis) as per the standard staining protocol as described for immunocytochemical staining. Flow cytometer (FACS Calibur, BD Bioscience, USA) settings were established using unstained cells. Data was analysed by Cell Quest Pro software (BD Bioscience, USA).

\section{$\underline{\text { References }}$}

Aflatoonian, B. and Moore, H. (2005) 'Human primordial germ cells and embryonic germ cells, and their use in cell therapy', Curr Opin Biotechnol 16: 530-535.

Aliborzi,G., Vahdati, A., Mehrabani, D., Hosseini, S.E., and Tamadon, A. (2016) 'Isolation, Characterization and Growth Kinetic Comparison of Bone Marrow and Adipose Tissue Mesenchymal Stem Cells of Guinea Pig', Int J Stem Cells 9(1): 115-123.

Asumda, F.Z. and Chase, P.B. (2011) 'Age-related changes in rat bone-marrow mesenchymal stem cell plasticity', BMC Cell Biol 12: 44.

Baltus, A,E., Menke, D.B. and Hu, Y.C. (2006) 'In germ cells of mouse embryonic ovaries, the decision to enter meiosis precedes premeiotic DNA replication' Nat Genet 38: 1430-1434. 
Bowles, J. and Koopman, P. (2007) 'Retinoic acid, meiosis and germ cell fate in mammals', Development 134: 3401-3411.

Brekhman, V., Itskovitz-Eldor, J., Yodko, E., Deutsch, M. and Seligman, J. (2000) 'The DAZL1 gene is expressed in human male and female embryonic gonads before meiosis', Mol Hum Reprod 6(5): 465-468.

Chen, H.H., Welling, M., Bloch, D.B., Muñoz, J., Mientjes, E., Chen, X., Tramp, C., Wu, J., Yabuuchi, A., Chou, Y.F., Buecker, C., Krainer, A., Willemsen, R., Heck, A.J. and Geijsen, N. (2014) 'DAZL limits pluripotency, differentiation, and apoptosis in developing primordial germ cells', Stem Cell Rep 3(5): 892-904.

Chen, Y. J., Liu, H. Y., Chang, Y. T., Cheng, Y. H., Mersmann, H. J., Kuo, and W. H., (2016) 'Isolation and Differentiation of Adipose-Derived Stem Cells from Porcine Subcutaneous Adipose Tissues', J. Vis. Exp. (109) e53886, doi:10.3791/53886.

Clark, A.T. and Reijo, P.R.A. (2006) 'Modeling human germ cell development with embryonic stem cells', Regen Med 1: 85-93.

Cooke, H.J., Lee, M., Kerr, S. and Ruggiu, M. (19996) 'A murine homologue of the human DAZ gene is autosomal and expressed only in male and female gonads'. Hum Mol Genet 5: 513-516.

Davies, O.G., Cooper, P.R., Shelton, R.M., Smith, A.J. and Scheven, B.A. (2015) 'Isolation of adipose and bone marrow mesenchymal stem cells using CD29 and CD90 modifies their capacity for osteogenic and adipogenic differentiation', Journal of Tissue Engineering. 6: 1-10.

Das, K., Madhusoodan, A.P., Mili, B., Kumar, A., Saxena, A.C., Kumar, K., Sarkar, M., Singh, P., Srivastaba, S. and Bag, S. (2017) 'Functionalized carbon nanotubes as suitable scaffold materials for proliferation and differentiation of canine mesenchymal stem cells', Int J Nanomedicine. 12: 3235-3252.

Drusenheimer, N.,Wulf, G., Nolte, J., Lee, J.H., Dev, A., Dressel, R., Gromoll, J., Schmidtke, J., Engel, W. and Nayernia, K. (2007) 'Putative human male germ cells from bone marrow stem cells', Soc ReprodFertil Suppl. 63: 69-76. 
Eslaminejad, M.B., Nikmahzar, A., Taghiyar, L., Nadri, S. and Massumi, M. (2006) 'Murine mesenchymal stem cells isolated by low density primary culture system', Dev Growth Differ 48: 361-370.

Francis, M.P., Sachs, P.C., Elmore, L.W. and Holt, S.E. (2009) 'Isolating adipose-derived mesenchymal stem cells from lipoaspirate blood and saline fraction', Organogenesis. 6(1): 1114.

Friedenstein, A.J., Deriglasova, U.F., Kulagina, N.N., Panasuk, A.F., Ruda-kowa, S.F. and Luria, E.A. (1974) 'Precursors for fibroblasts in different populations of hematopoietic cells as detected by the in vitro colony assay method', Exp Hematol 2: 83-92.

Geijsen, N., Horoschak, M., Kim, K., Gribnau, J., Eggan, K. and Daley, G.Q. (2004) 'Derivation of embryonic germ cells and male gametes from embryonic stem cells', Nature 427: 106-107.

Ginsburg, M., Snow, M.H.L. and McLaren, A. (1990) 'Primordial germ cells in the mouse during gastrulation', Development 110: 521-528.

Hayashi, K., de Sousa Lopes, S.M. and Surani, M.A. (2007) 'Germ cell specification in mice', Science 316: 394-396.

Hoyer, P.E., Byskov, A.G. and Mollgard, K. (2005) 'Stem cell factor and c-Kit in human primordial germ cells and fetal ovaries', Mol Cell Endocrinol 234: 1-10.

Huang, P., Lin, L.M., Wu, X.Y., Tang, Q.L., Feng, X.Y., Lin, G.Y., Lin, X., Wang, H.W., Huang, T.H. and Ma, L. (2010) 'Differentiation of human umbilical cordWharton's jellyderivedmesenchymal stem cells into germ-like cells in vitro', J Cell Biochem 109: 747-754.

Hunt, P., Robertson, D., Weiss, D., Rennick, D., Lee, F. and Witte, O.N. (1987) 'A single bone marrow-derived stromal cell type supports the in vitro growth of early lymphoid and myeloid cells Cell', 48: 997-1007.

Jiang, Y., Jahagirdar, B.N., Reinhardt, R.L., Schwartz, R.E., Keene, C.D. and Ortiz-Gonzalez, X.R. (2002) 'Pluripotency of mesenchymal stem cells derived from adult marrow', Nature 418: 41-49. 
Koubova, J., Menke, D.B., Zhou, Q., Capel, B., Griswold, M.D. and Page, D.C. (2006) 'Retinoic acid regulates sex-specific timing of meiotic initiation in mice', Proc Natl Acad Sci USA 103: 2474-2479.

Kumar, K., Agarwal, P., Das, K., Milli, B., Madhusoodan, A.P., Kumar, A. and Bag, S. (2016) 'Isolation and characterization of mesenchymal stem cells from caprine umbilical cord tissue matrix', Tissue and cell 48 (6): 653-658.

Kumar, K., Singh, R., Kumar, M., Agarwal, P., Mahaparta, P.S., Kumar, A., Malakar, D. and Bag, S. (2014) 'Isolation and characterization of buffalo neural stem cells', International journal of Neuroscience 124: 450-456.

Kumar, M., Yasotha, T., Singh, R.K., Singh, R., Kumar, K., Ranjan, R., Meshram, C.D., Das B.C. and Bag S.(2013) 'Generation of transgenic mesenchymal stem cells expressing GFP as reporter gene using no viral vector in caprine' Indian Journal of experimental biology 51: 502509.

Lacham, K.O., Chy, H. and Trounson, A. (2006) 'Testicular cell conditioned medium supports differentiation of embryonic stem cells into ovarian structures containing oocytes', Stem Cell 24: 266-273.

Lacham-Kaplan, O. (2004) 'In vivo and in vitro differentiation of male germ cells in the mouse', Reproduction 128: 147-152.

Lange, U.C., Saitou, M., Western, P.S., Barton, S.C. and Surani, M.A. (2003) 'The fragilis interferoninducible gene family of transmembrane proteins is associated with germ cell specification in mice', BMC Dev Biol 3: 1.

Lange-Consiglio, A., Corradetti, B., Meucci, A., Perego, R., Bizzaro, D. and Cremonesi, F. (2013) 'Characteristics of equine mesenchymal stem cells derived from amnion and bone marrow: in vitro proliferative and multilineage potential assessment', Equine Vet J 45:737-744.

Li, Y., Wang, X. and Feng, X. (2014) 'Generation of male germ cells from mouse induced pluripotent stem cells in vitro', Stem Cell Res 12: 517-530. 
Lotfy, A., Salama, M., Zahran, F., Jones, E., Badawy, A. and Sobh, M. (2014) 'Characterization of Mesenchymal Stem Cells Derived from Rat Bone Marrow and Adipose Tissue: A Comparative Study', International Journal of Stem Cells 7(2): 135-142.

Mark, M., Jacobs, H. and Oulad-Abdelghani, M. (2008) 'STRA8-deficient spermatocytes initiate, but fail to complete, meiosis and undergo premature chromosome condensation', J Cell Sci 121: 3233-3242.

Mazaheri, Z., Movahedin, M., Rahbarizadeh, F. and Amanpour, S. (2011) 'Different doses of bone morphogenetic protein 4 promote the expression of early germ cell-specific gene in bonemarrow mesenchymal stem cells', In Vitro Cell Dev Biol Anim 47: 521-525.

Medrano, J.V., Ramathal, C., Nguyen, H.N., Simon, C. and Reijo Pera, R.A. (2012) 'Divergent RNA-binding proteins, DAZL and VASA, induce meiotic progression in human germ cells derived in vitro', Stem Cells 30: 441-451.

Meirelles, L.D.A S. and Nardi, N.B. (2003) 'Murine marrow-derived mesenchymal stem cell: isolation, in vitro expansion, and characterization', Br J Haematol 123: 702-711.

Miano, J.M. and Berk, B.C. (2001) 'Retinoids: new insight into smooth muscle cell growth inhibition', Arterioscler Thromb Vasc Biol 21: 724-726.

Nayernia, K., Lee, J.H., Drusenheimer, N., Nolte, J., Wulf, G., Dressel, R., Gromoll, J. and Engel, W. (2006) 'Derivation ofmalegermcellsfrombone marrow stem cells', Lab Investig, 86: 654-63.

Niu, Z., Hu, Y., Liao, M., Yu, M., Zhu, H., Wang, L., Wu, J., Bai, C., Li, G. and Hua, J. (2014) 'Conservation and function of Dazl in promoting the meiosis of goat male germline stem cells', Mol Biol Rep 41(5): 2697-2707.

Niyaz, M., Gurpinar, O.A., Gunaydin, S. and Onur, M.A. (2012) 'Isolation, culturing and characterization of rat adipose tissuederived mesenchymal stem cells: a simple technique' Turk J Biol 36: 658-664.

Oulad-Abdelghani, M., Bouillet, P., Decimo, D., Gansmuller, A., Heyberger, S., Dolle, P., Bronner, S., Lutz, Y. and Chambon, P. (1996) 'Characterization of a premeiotic germ cell- 
specific cytoplasmic protein encoded by Stra8, a novel retinoic acid-responsive gene', J Cell Biol, 135: 469-477.

Pittenger, M.F., Mackay, A.M., Beck, S.C., Jaiswal, R.K., Douglas, R., Mosca, J.D., Moorman, M.A., Simonetti, D.W., Craig, S. and Marshak, D.R. (1999) 'Multilineage potential of adult human mesenchymal stem cells', Science 284: 143-147.

Prockop, D.J. (1997) 'Marrow stromal cells as stem cells for nonhematopoietic tissues', Science 276: 71-74.

Qiu P., Bai Y., Pan S., Li, W., Liu, W. and Hua, J. (2013) 'Gender depended potentiality of differentiation of human umbilical cord mesenchymal stem cells into oocyte-Like cells in vitro', Cell Biochem Funct 31: 365-373.

Quiroz, F.G., Estefan, O.M.P., Perez, D.G., Castro, N.H., Velasquez, C.A.S., Hansford, D. J., Florez, P.A. and Rojas L.E.L. (2008) 'Isolation of human bone marrow mesenchymal stem cells and evaluation of their osteogenic potential', Revista Ingenieria Biomedica 2: 48-55.

Ramos-Ibeas, P., Pericuesta, E., Fernandez-Gonzalez, R., Gutierrez- Adan, A. and Ramirez, M.A. (2011) 'Characterisation of the deleted in azoospermia like (Dazl)-green fluorescent protein mouse model generated by a two-step embryonic stem cell-based strategy to identify pluripotent and germ cells', Reprod Fertil Dev doi:10.1071/RD14253.

Raoufi, M.F., Tajik, P., Dehghan, M.M., Eini, F. and Barin, A. (2011) 'Isolation and Differentiation of Mesenchymal Stem Cells From Bovine Umbilical Cord Blood', Reprod Domest Anim 46: 95-99.

Saitou M, Barton SC and Surani MA. (2002) 'A molecular programme for the specification of germ cell fate in mice', Nature 418: 293-300.

Saitou M. (2009) 'Germ cell specification in mice. Curr Opin Genet Dev’, 19: 386-395.

Shinohara, T., Avarbock, M.R. and Brinster, R.L. (1999) 'Beta1- and alpha6-integrin are surface markers on mouse spermatogonial stem cells', Proc Natl Acad Sci USA 96: 5504-5509.

Shirazi, R., Zarnani, A.H., Soleimani, M., Abdolvahabi, M.A., Nayernia, K. and Ragerdi, K.I. (2012) 'BMP4 can generate primordial germ cells from bone-marrow-derived pluripotent stem cells', Cell Biol Int 36: 1185-1193. 
Silva, C., Wood, J.R., Salvador, L., Zhang, Z., Kostetskii, I., Williams, C.J and Strauss, J.F. (2009) 'Expression profile of male germ cell-associated genes in mouse embryonic stem cell cultures treated with all-trans retinoic acid and testosterone', Mol Reprod Dev 76: 11-21.

Sun, C.K., Yen, C.H., Lin, Y.C., Tsai, T.H., Chang, L.T., Kao, Y.H., Chua, S., Fu, M., Ko, S.F., Leu, S. and Yip, H.K. (2011) 'Autologous transplantation of adipose-derived mesenchymal stem cells markedly reduced acute ischemia-reperfusion lung injury in a rodent model', J Transl Med 9: $118-120$.

Sung, J.H., Yang, H.M., Park, J.B., Choi, G.S., Joh, J.W., Kwon, C.H., Chun, J.M., Lee, S.K, and Kim, S.J. (2008) 'Isolation and Characterization of Mouse Mesenchymal Stem Cells', Transplantation Proceedings 40(8): 2649-54.

Tilgner, K., Atkinson, S.P., Golebiewska, A., Stojkovic, M., Lako, M. and Armstron, L. (2008) 'Isolation of primordial germ cells from differentiating human ES cells', Stem Cells 26: 30753085.

Vincent, S., Segretain, D., Nishikawa, S.I., Sage, J., Cuzin, F. and Rassoulzadegan, M. 'Stagespecific expression of the Kit receptor and its ligand (KL) during male gametogenesis in the mouse: a Kit- KL interaction critical for meiosis', Development 125: 4585-4593.

Wang, P.J., McCarrey, J.R., Yang, F. and Page, D.C. (2001) 'An abundance of X-linked genes expressed in spermatogonia', Nat Genet 27: 422-426.

Wobus, A.M., Guan, K., Yang, H.T. and Boheler, K.R. (2002) 'Embryonic stem cells as a model to study cardiac, skeletal muscle, and vascular smooth muscle cell differentiation', Methods Mol Biol 185: 127-156, 2002.

Yamauchi, K., Hasegawa, K., Chuma, S., Nakatsuji, N. and Suemori, H. (2009) 'In vitro germ cell differentiation from cynomolgus monkey ES cells', PloS One 4: 5338.

Zangi, L., Rivkin, R., Kassis, I., Levdansky, L., Marx, G., and Gorodetsky, R. (2006) 'HighYield Isolation, Expansion, and Differentiation of Rat Bone Marrow-Derived Mesenchymal Stem Cells with Fibrin Microbeads;', Tissue Engineering 12: 2343-2354. 
bioRxiv preprint doi: https://doi.org/10.1101/418962; this version posted September 15, 2018. The copyright holder for this preprint (which was not certified by peer review) is the author/funder. All rights reserved. No reuse allowed without permission.

A
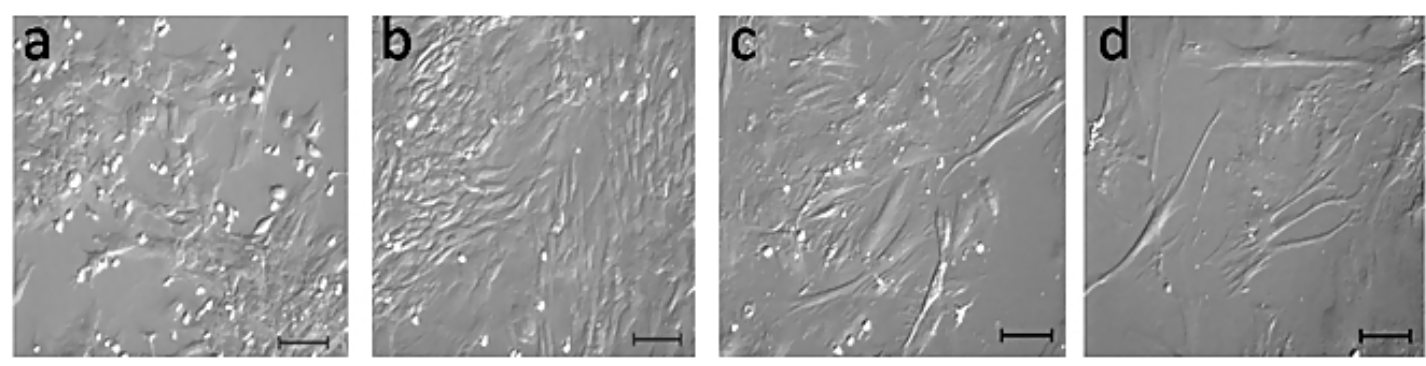

$\mathrm{C}$
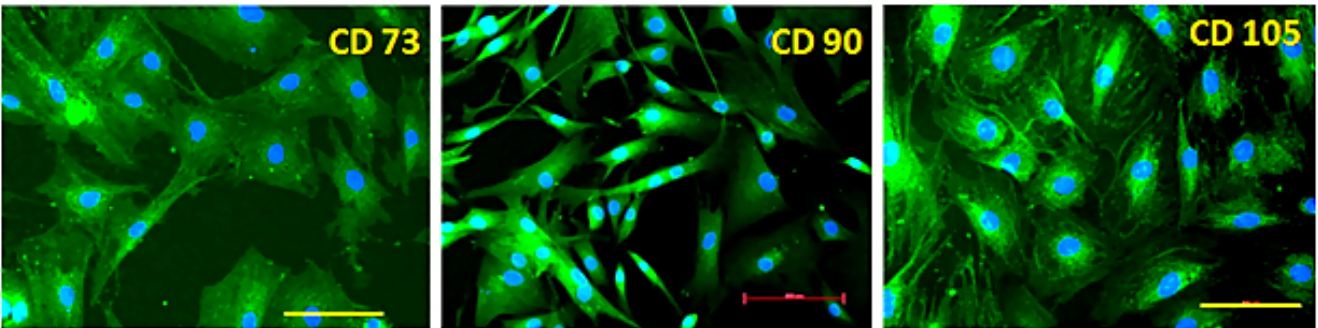

D

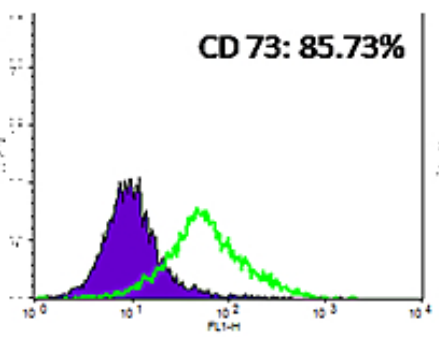

$\mathbf{E}$

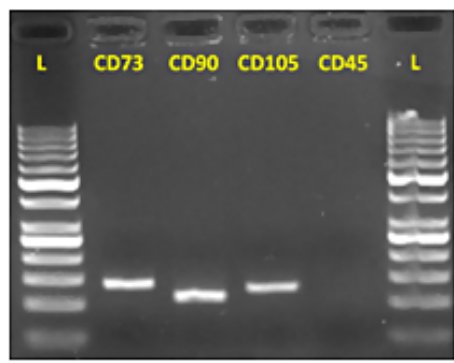

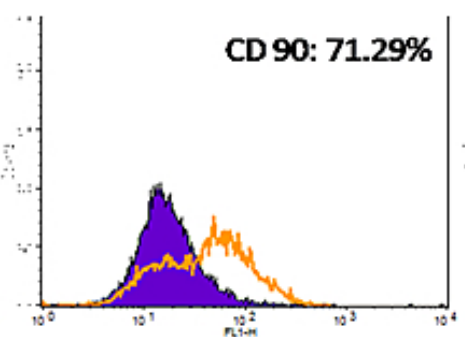

$\mathbf{F}$

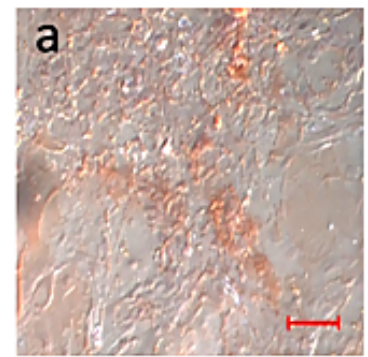

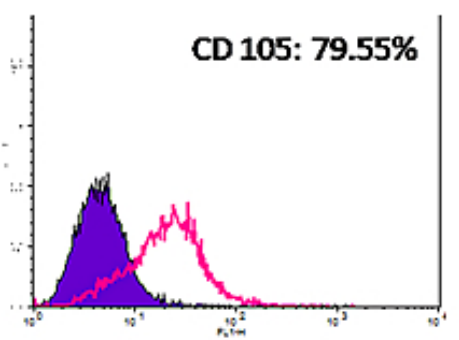

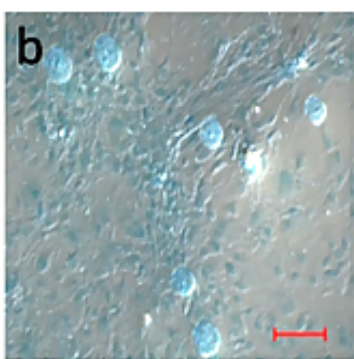

B a

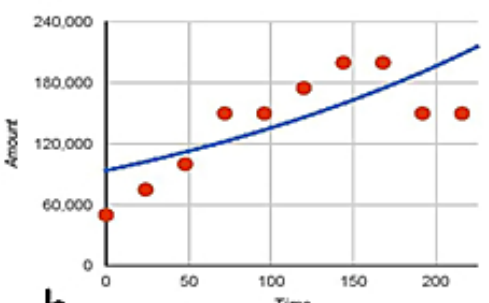

b

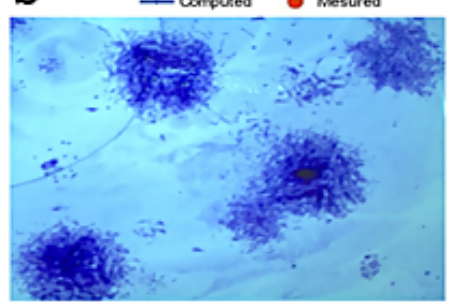


bioRxiv preprint doi: https://doi.org/10.1101/418962; this version posted September 15, 2018. The copyright holder for this preprint (which was not certified by peer review) is the author/funder. All rights reserved. No reuse allowed without permission.

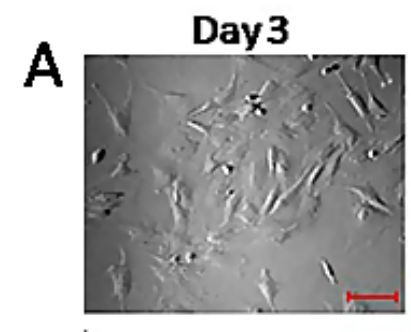

Day 7

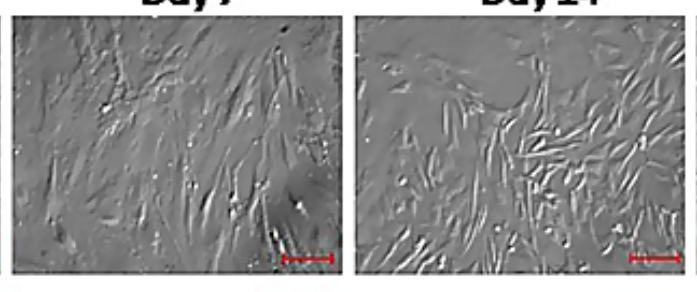

Day 21

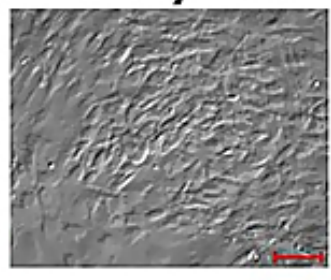

Control (without retinoic acid)

B
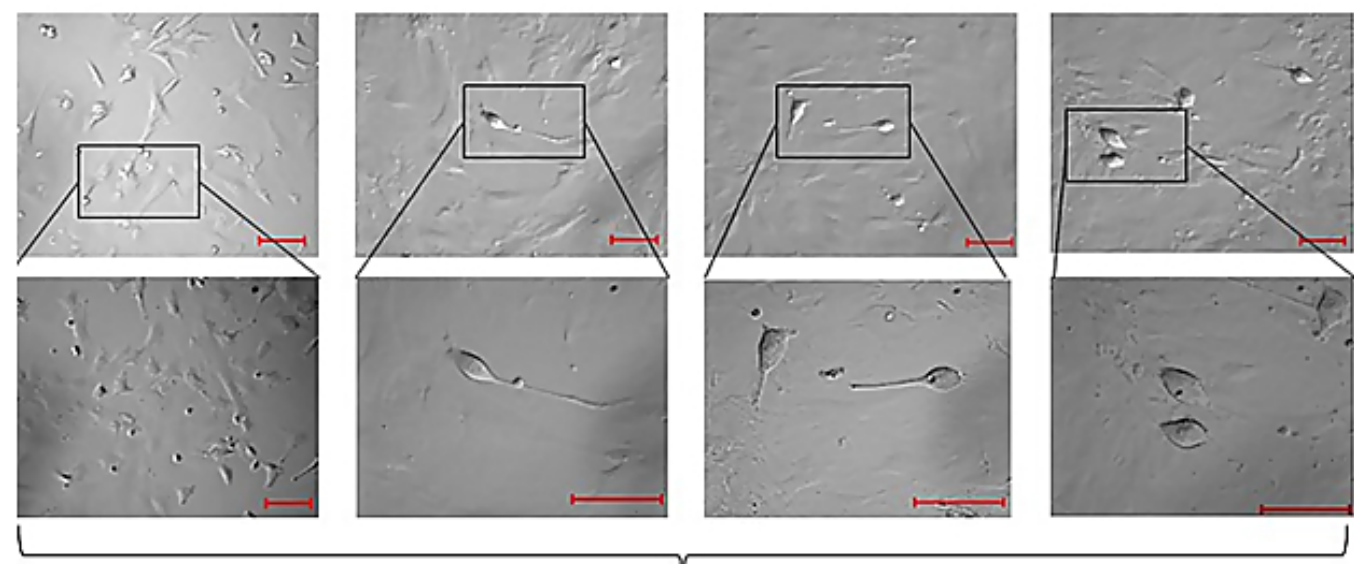

Differentiated (with retinoic acid) 
bioRxiv preprint doi: https://doi.org/10.1101/418962; this version posted September 15, 2018. The copyright holder for this preprint (which was not certified by peer review) is the author/funder. All rights reserved. No reuse allowed without permission.

A
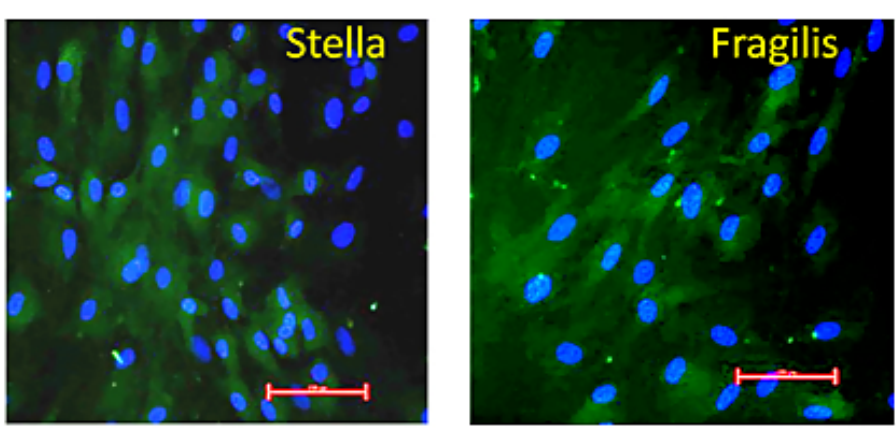

B

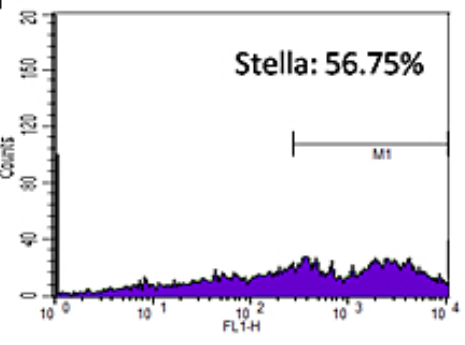

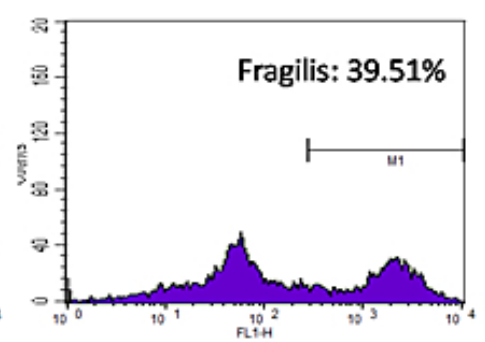

C
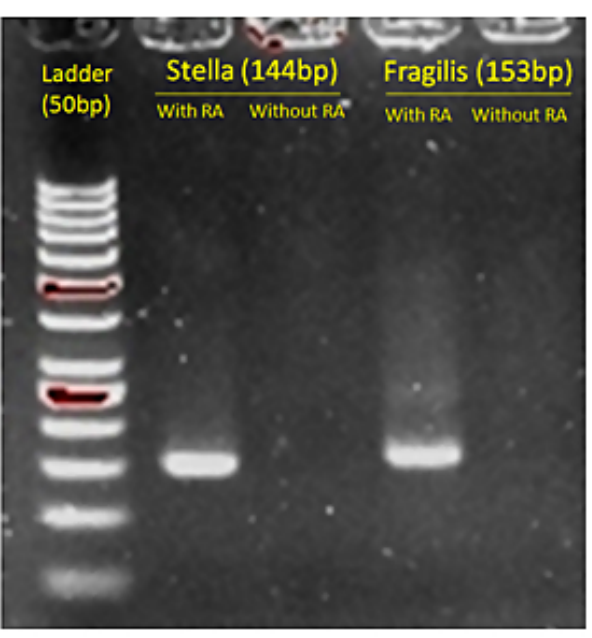

D

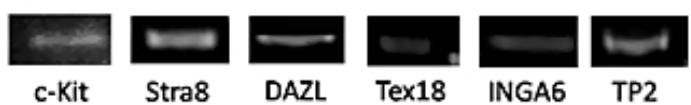


Figure. 1: (A-F) Characterization of rMSCs. (A) Morphology of rMSC at different passage (a)P 0, (b) P1, (c) P4 and (d) P6. (B) (a) Growth curve and (b) CFU assay of rMSC (C). Immunofluorescence staining of MSC specific surface markers CD 73, 90 and 105 (D) Values represent the mean percentage of positively stained cells as analyzed by flow cytometry (E) Expression of MSC specific genes assessed by RT-PCR (F) Differentiation potential of rMSCs into mesodermal lineages. (a) osteocytes (alizarin red staining), (b) chondrocytes (alcian blue staining). Scale bar $=100 \mu \mathrm{m}$

Figure 2: In Vitro Differentiation of rMSC into germ cell-like cells on different days. (A) Control undifferentiated (B) Differentiated with RA supplementation. Scale bar $=100 \mu \mathrm{m}$.

Figure 3: In Vitro characterization of germ cell-like cells. (A) Immunofluorescence staining after

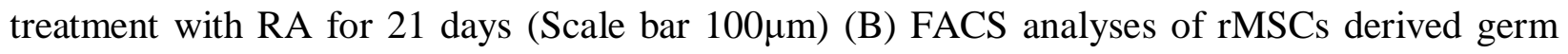
cells, labeled with FITC conjugated antibodies against Stella (56.75\%) and Fragilis (39.51\%) (C) Molecular characterization of rMSC differentiated cells into germ cells by Stella and Fragilis (D) Molecular study of spermatogonial stem cells markers - c-Kit, Stra8, Dazl, tex18, Inga6 and TP2 
Table 1: List of primers used in the study

\begin{tabular}{|c|c|c|c|}
\hline S. No & Genes & Primer sequence & Product (bp) \\
\hline 1 & CD 73 & $\begin{array}{l}\text { F: 5' ctggtcaacggtggggatggattc } 3^{\prime} \\
\text { R: 5' tccgtccttcaactgctgggtaaa } 3^{\prime}\end{array}$ & 136 \\
\hline 2 & CD 90 & $\begin{array}{l}\text { F: 5' gccagaatcccacaagctccaata } 3^{\prime} \\
\text { R: 5' ggagcagcagcagccaggaagtg } 3^{\prime}\end{array}$ & 111 \\
\hline 3 & CD 105 & $\begin{array}{l}\text { F: 5' cccccgtacgtctcctggctcatc } 3^{\prime} \\
\text { R: 5' ggggtgtgtctgggagctcgaa } 3^{\prime}\end{array}$ & 124 \\
\hline 4 & CD45 & $\begin{array}{l}\text { F: 5' agggcaaggaacaaccgacgatgg } 3^{\prime} \\
\text { R: 5' ggagcagccgtgagtgtggtgag } 3^{\prime}\end{array}$ & 147 \\
\hline 5 & Stella & $\begin{array}{l}\text { F: 5' ccagtgccaagccgacaaaatatcat } 3^{\prime} \\
\text { R: 5' cggacaacagagtgcggaccc } 3{ }^{\prime}\end{array}$ & 144 \\
\hline 6 & Fregilis & $\begin{array}{l}\text { F: 5' aaggaagaatatgaggtggctgagatgg 3' } \\
\text { R: 5' gcccaggcagcagaagttcatgaagagt 3' }\end{array}$ & 153 \\
\hline 7 & c-Kit & $\begin{array}{l}\text { F: 5' gcgectgccgaaatgtatgacg } 3^{\prime} \\
\text { R: 5' tgtgettggtgctgtccgagatct } 3^{\prime}\end{array}$ & 121 \\
\hline 8 & INGA6 & $\begin{array}{l}\text { F: 5' ccaggtggcccagcatcaatgtg 3' } \\
\text { R:5' tgcctgtgacctccggggacc } 3^{\prime}\end{array}$ & 128 \\
\hline 9 & Dazl & $\begin{array}{l}\text { F: 5' tgacgtggatgtgcagaagatagtaga } 3^{\prime} \\
\text { R: 5' tggcggaggaggaggattaaa } 3^{\prime}\end{array}$ & 145 \\
\hline 10 & Tex18 & $\begin{array}{l}\text { F: 5' ggccacctagcaatcaccaactcagaga 3' } \\
\text { R: 5' ttgggtggtgtgtgtgtgtgtctgatct } 3^{\prime}\end{array}$ & 140 \\
\hline 11 & Stra8 & $\begin{array}{l}\text { F: 5' tgccgecatctcccacctgt } 3^{\prime} \\
\text { R: 5' ccccggccagctctagacagg } 3^{\prime}\end{array}$ & 125 \\
\hline 12 & $\mathrm{TP} 2$ & $\begin{array}{l}\text { F: 5' cgccgacgaagcaccccaaaac 3' } \\
\text { R: 5' tccgectcetgaccgcctttctct 3' }\end{array}$ & 135 \\
\hline
\end{tabular}

